The reference of original published paper \& citations required:

A. Länsiluoto, E. Varamäki, E.K. Laitinen, A. Viljamaa and J. Tall (2016) Management control systems in small business transfers: a resource-based view. Journal of Enterprising Culture, Vol. 23 No. 4, pp. 449-471. (DOI: http://dx.doi.org/10.1142/S0218495815500156)

\title{
Management control systems in small business transfers: a resource-based view
}

Aapo Länsiluoto (corresponding author)*,**

Elina Varamäki*

Erkki K. Laitinen***

Anmari Viljamaa*

Juha Tall*

*Seinäjoki University of Applied Sciences; School of Business and Culture, Seinäjoki, Finland ** aapo.lansiluoto@seamk.fi

***University of Vaasa; Accounting and finance, Vaasa, Finland 


\title{
Management control systems in small business transfers: a resource-based view
}

\begin{abstract}
This study investigates whether post-business transfer MCS development (PBTMCSD) is associated with post-business transfer success (PBTS) in small firms. The data for the study was collected in January 2012 as a web-based survey. The target group consisted of acquirers (both external buyers and family business successors) who had implemented a business transfer during 2006-2011 in Finland. A total of 178 questionnaires were sent out, and 67 responses were received. Regression analysis is used to investigate the relationship between PBTMCSD and PBTS. We utilize both resource-based view (RBV) and contingency theory.

The results indicate that PBTMCSD has a positive and significant relation with PBTS. Our findings highlight the importance of PBTMCSD even in small companies in the context of business transfer. However, the relationship between PBTMCSD and PBTS performance was stronger for firms with five or more employees as well as firms with previous experience of business transfers.
\end{abstract}

Keywords: Business transfers, Acquisitions, Management control systems, Success, Small firms, Survey

\section{Introduction}

Small and medium-sized enterprises (SMEs), by numbers, dominate the world and European business environment. In the 27 countries of the European Union, SMEs account for $99.8 \%$ of all enterprises, employ $67 \%$ of all workers and contribute $58 \%$ of gross value added (Edinburgh group, 2015; Wymenga et al., 2012). These small firms have traditionally tended to follow an organic growth strategy, while larger growth firms follow acquisitive growth strategy i.e. they increase their business and grow through mergers and acquisitions (e.g. Delmar et al., 2003; see also Agarwal \& Helfat, 2009). Acquisitive growth strategy is, however, gaining popularity among small businesses as well (see e.g. Delmar et al., 2003; Agarwal \& Helfat, 2009; Shi et al., 2012; Van Teeffelen, 2012). There are more and more studies available indicating that transferred businesses outperform start-ups with respect to survival, turnover, profit, innovativeness and employment (e.g. Kohn and Spengler, 2009; Van Teeffelen, 2012). Survival for five years, depending on the economic climate, generally ranges somewhere between $35-50 \%$ for startups, while the figure for transferred firms is 90-96\% (Geerts et al., 2004; Kohn and Spengler, 2009). 
The fact that transferred businesses outperform start-ups is of particular relevance at a time when the European population, including entrepreneurs, is aging. The aging of entrepreneurs will have considerable effects on the business transfer markets. Based on estimates, approximately 450000 firms are being transferred each year across Europe, affecting two million employees (European Commission, 2011).

The estimated volume of business transfers around Europe offers great potential for both entrepreneurs to grow their existing businesses with an acquisitive strategy and also for entrepreneurs to start by buying a firm. According to recent surveys, approximately 15-35\% of SMEs will find a successor inside the family, but almost $40 \%$ of firms are looking for external buyers (Battisti and Okamuro, 2010; CSES, 2013; Varamäki et al., 2014). All in all, business transfers are essential to the vitality and performance of national economies (e.g. Dyck et al., 2002; Kohn and Spengler, 2009; Van Teeffelen, 2012). The scope and importance of the business transfer phenomenon well justifies an interest in the growth and development of transferred businesses.

Business transfers, i.e. acquisitions have been a popular research area in recent years among larger firms but not so popular among small firms. The study of business transfers began with family firm researchers at the turn of the millennium (e.g. Lansberg, 1988; Le Breton-Miller et al., 2004; Morris et al., 1997). Interest in non-family transfers was triggered by the massive expected numbers of business transfers (European Commission, 2002) and the increasing empirical evidence that the proportion of family transfers in SMEs is decreasing (Battisti and Okamuro, 2010; Howorth et al., 2004; Varamäki et al., 2014). In this study, we refer to a broader definition of business transfers that includes both transfers with external buyers (coming from 
outside the family) and successions in family firms (successors come from within the family). The main focus of business transfer studies is to predict and model success and failure of the ownership transitions and the post-transfer performance of transferred firms.

The business transfer process can be seen as a complex, multifaceted, and multi-temporal phenomenon (Meglio and Risberg, 2010), in which competitive advantages are sought. Motivations presented for business transfer include: diversification into new markets, extension into new geographic markets, increasing the firm's market share, inefficient management of target firms or acceleration of growth (Granlund, 2003; Grant, 1991; Haspeslagh and Jemison, 1991; Kreitl and Oberndorfer, 2004). Business transfers support business growth (e.g. Barkema and Schijven, 2008; Uhlaner and West, 2008) and strategic renewal (Barney, 2001; Haspeslagh and Jemison, 1991; Priem and Butler, 2001; Varamäki et al., 2012). Yet there is also a great deal of empirical evidence of failure in business transfers (e.g. Baker et al., 2012; Chatterjee, 2009; Marks and Mirvis, 2001; Seth et al., 2002; Sharma et al., 2003), suggesting there is a need to seek better understanding of factors that promote successes or cause failures after transfer.

According to the resource-based view (RBV), success can be based upon resources that are critical or difficult to imitate (Barney et al., 2001; Grant, 1991; Wernerfelt, 1984). As Wernerfelt (1984) proposes, an acquisition is one way to get such resources. Buyer entrepreneurs and buyer firms may have critical resources that can be combined in an innovative way with resources of the acquired firm (Barney et al., 2001; Grant, 1991; Wernerfelt, 1984). Resource-based acquisition strategies are supplementary or complementary (Wernerfelt, 1984). That is, acquirers get more of the type of resources they already have, or they get resources which combine effectively with those they already have. Management control systems (MCS) can be similarly 
seen as supplementary and complementary resources. MCS can be considered, like IT systems, a resource and a part of technological capital. This study utilizes the definition of Malmi and Brown (2008), according to whom management controls include all the devices and systems managers use to ensure that the behavior and decisions of employees are consistent with the organization's objectives and strategies. MCS can provide information for decision making and control which can be utilized by skilled users (see Barney et al., 2001; Chenhall and Euske, 2007; Hoque and Chia, 2012), and hence may have a crucial role in organizational change processes such as acquisitions or successions.

There are some studies which have considered MCS or performance measurement systems (PMS) in a SMEs' context. SMEs differ from larger firms in several characteristics which can have an impact on the adoption of MCS (e.g. Ates et al., 2013; Garengo et al., 2005; Taticchi et al., 2010). For instance Garengo et al. (2005), Ates et al., 2013) found in their literature review that SMEs' have: scarce human resources, lack of managerial intellectual capacity, limited capital resources, reactive approach to management and do not have formalized processes, all of which result in challenges to MCS implementation. Rather than well-developed MCS (such as cost or different management accounting techniques), MCS in SMEs are often focused on financial accounting such as basic income and balance sheet analysis (Teittinen et al., 2013). One reason for non-adoption of sophisticated MCS may be that MCS are developed for the purposes of larger companies (Ates et al., 2013; Taticchi et al., 2010 see also Chenhall, 2003). Another reason may be that SMEs managers and owners may have good personal networks to gather information and thus may view MCS as unnecessary for managerial purposes (Ates et al., 2013). 
However, despite their special characteristics, MCS could also be beneficial for SMEs. Teittinen et al. (2013), Ates et al., (2013) and Garengo et al., (2005) found that MCS could benefit SMEs in implementing and controlling strategy. MCS could also help to focus on stakeholders and process management initiatives, as well as produce different performance measurement information for decision making purposes (Garengo et al., 2005). However, there is still only limited research on whether MCS are appropriate for SMEs. Taticchi et al. (2010) specifically encourage future research to investigate MCS effectiveness, efficiency and adaptability in SMEs. In our study, we respond to their recommendation within the context of business transfers.

Change in accounting or management control systems has so far received little attention in studies on SME business transfers, although it has been a popular research field in recent years in the context of large companies' mergers and acquisitions (M\&A) (e.g. Chenhall and Euske, 2007; Granlund, 2003; Hoque and Chia, 2012). Contrary to large firms, in small firm business transfers the existing MCS of the acquirer may be undeveloped, suggesting that MCS development rather than MCS integration should be addressed in the transfer. Neither integration of old nor development of new MCS has been examined in SME business transfer contexts. Ates et al. (2013) propose that SMEs should take a more strategic and long-term view of MCS change rather than seeing it as a matter of project management only. As business transfers naturally call for reflection on long-term goals, they afford an opportunity for consideration of MCS development as well.

Moreover, the SME business transfer context differs in some respects from organizational change situations such as investments or strategic changes: SME business transfers frequently comprise uncertainties such as information asymmetry between the acquirer and the acquired firm. The 
contingency theory proposes that use of MCS is dependent on the organizational contextual characteristics such as environmental uncertainty, size, strategy or organizational structure (Chenhall, 2003; Grant, 1991; Reheul and Jorissen, 2014; Tsamenyi et al., 2011). According to contingency theory (Chenhall, 2003), MCS do not have an essential role in small firms which can be managed with other modes such as informal MCS (i.e. brainstorming and conversations) (Hutchinson and Quintas, 2008). However, with the heightened uncertainties of the business transfer context, MCS might also play a key role in small firms, contradicting the size effect proposition of contingency theory. Greater environmental uncertainty has been predicted to increase reliance on MCS (Chenhall, 2003). In sum, contingency theory does not provide a clear answer for how MCS are applied in small firms in business transfer context (i.e. high uncertainty condition). Therefore, the purpose of this study is to investigate whether post-business transfer MCS development (hereafter PBTMCSD) is associated with post-business transfer success (hereafter PBTS) in small firms. This means that our study is focusing on MCS development and success in the context of post-business transfer.

The structure of the rest of the paper is as follows. First, we present our theoretical model and hypotheses. Second, we describe the methods used for this study. Third, we present our empirical results, which show a relationship between PBTMCSD and PBTS in the post-business transfer context. Finally, we discuss the findings in light of RBV and contingency theories and present conclusions, limitations, and implications for further research as well as some practical implications. 


\section{Hypothesis development}

\section{Theoretical framework}

Earlier studies have found that acquisition in general improves the profitability (e.g. Guest et al., 2010) or sales growth (Arvanitis and Stucki, 2014 see also Van Teeffelen, 2012) of the acquirer. Planning and managing the post-acquisition integration is however one of the key success factors in business transfers (Haspeslagh \& Jemison, 1991; Stahl et al., 2011), and the role of PBTMSCD in PBTS has not been analyzed empirically. Furthermore, other performance criteria beyond financial performance may apply in the business transfer context, including future acquisition likelihood (e.g. Peng and Fang, 2010), employee satisfaction after the business transfer (e.g. Marks and Mirvis, 1992; Risberg, 2001), innovation (Arvanitis and Stucki, 2014), strategic fit and personal motives of an entrepreneur (e.g. Angwin, 2007; Seth et al., 2002).

In line with earlier MCS studies (Luft and Shields, 2003 see also Halabi and Lussier, 2014), our model assumes that MCS are helpful in the post-business transfer context. Therefore, PBTMCSD is expected to have a positive relationship with PBTS. Further, following previous contingency theory studies (Chenhall, 2003), our model proposes that the relationship between PBTMCSD and PBTS is affected by the size of the acquired firm and also, viewing previous experience of business transfers as an inimitable and a non-substitutable resource which can create competitive advantage as suggested by RBV (Peng and Fang, 2010), by previous business transfer experience.

The theoretical model of the study is presented in Figure 1 and described more in detail in the following sections. 


\section{INSERT FIGURE 1 ABOUT HERE}

\section{PBTMCSD and PBTS}

RBV has been a popular theory in MCS research (e.g. Franco-Santos et al., 2012), and it provides an explanation for how PBTMCSD can be beneficial. The fundamental concept in RBV is resource. According to Wernerfelt (1984), a resource is anything which could be thought of as a strength or weakness of a given firm. Grant (1991) describes six categories of resources; financial, physical, human, technological, reputation and organizational resources. In this categorization MCS can be considered as a technological resource. Grant (1991) concludes the key of RBV is in understanding the relationship between resources, capabilities, competitive advantage and profitability. MCS reflect organization-specific characteristics and are tailored for determined purposes in an organization. Hence, MCS can be viewed as a unique resource for firms and, in the context of business transfers, PBTMCSD can be critical for PBTS in SMEs.

PBTS can be measured in different ways (Meglio and Risberg, 2011; Zollo and Meier, 2008). Although acquisition performance has been a part of strategic management literature for decades, there is no agreement on how to measure acquisition performance. Zollo and Meier (2008) identified 12 significantly different approaches based on the level of analysis and the time horizon. According to Meglio and Risberg (2011), the success measures of M\&As have been either financial (market or accounting performance) or non-financial (operational or overall performance) (Meglio and Risberg, 2011). For instance Zollo and Meier (2008) found that accounting and financial performances were positively associated with the overall acquisition

performance. Furthermore, integration process performance had a positive correlation with 
financial performance but, interestingly, a statistical insignificant correlation with accounting performance. However, the study of Zollo and Meier (2008) did not focus on PBTMCSD specifically which implicates the need for our study in the context of SME business transfer.

MCS can enhance knowledge management, communication and co-ordination (Nixon and Burns, 2012), all of which can be considered important in the business transfer context. PBTMCSD may be motivated by the need to produce more relevant information for different actions. Another purpose of PBTMCSD can relate to trust. PBTMCSD activities are aimed at improving the alignment between the scope of produced information and the requirements of the acquirer (Laitinen et al., 2009; Tillema, 2005). The existence of MCS alone may not however have an effect on PBTS: the MCS should actually provide relevant information for decision-making. For instance Barney et al. (2001) propose that competitive advantage might not be created (and ultimately therefore financial or non-financial success not realized) if the MCS fails to monitor and/or incentivize management to undertake relevant actions. To summarize, PBTMCSD seems important for PBTS because it supports creation of trust and enables production of relevant information for different decision-making situations.

Various factors that may affect PBTMCSD are suggested by the case studies of Granlund (2003) and Moilanen (2008). Granlund (2003) found that goal ambiguity, cultural conflicts, unintended consequences and dominant individuals can crucially delay the MCS development process. Granlund (2003, see also Chenhall and Euske, 2007) proposes that MCS may provide a common language which helps in coordinating and communicating norms and values. Such coordination activities can be considered important in business transfers. Granlund (2003) emphasizes that the information provided by MCS should be comparable, although different companies may have 
different MCS. Comparability can enhance trust in information. Trust can also be enhanced if the numbers can be broken into smaller and smaller parts (Moilanen 2008).

To summarize, after a business transfer there is a need to ensure that the MCS provide relevant information for decision making and control, hence the need for PBTMCSD. The resulting relevant information can be used for decisions on pricing, process reorganization and new product selection, which all relate to PBTS. Therefore, our first hypothesis is as follows:

\section{H1: PBTMCSD has a positive relationship with PBTS}

\section{Size and experience moderate the relationship between PBTMCSD and PBTS}

The contingency theory predicts that larger firms, due to their higher complexity, benefit more from MCS systems (e.g. Chenhall, 2003 see also Reheul and Jorissen, 2014). In addition to the greater expected benefits, larger firms also have more resources for PBTMCSD. Hutchinson and Quintas (2008) propose that MCSs are designed for the specific requirements of larger organizations. Therefore, it seems reasonable that also in the business transfer context firm size has an impact on the benefits gained from PBTMCSD.

The relationship between PBTMCSD and PBTS might also be moderated by the business transfer experience of the acquirer. According to Peng and Fang (2010), earlier business transfer experience can be viewed as an inimitable and a non-substitutable resource. As business transfer experience is accumulated, also the capabilities for conducting further business transfers develop (Arikan and McGahan, 2010). Such capabilities may relate to the analysis of acquired firm (i.e. 
before business transfer), the formulation of agreements (i.e. during the transfer process) or firm development activities (i.e. after business transfer), e.g. PBTMCSD.

Experienced acquirers can be termed habitual entrepreneurs. Traditionally, habitual entrepreneurs are further divided into serial and portfolio entrepreneurs based on whether they own their firms chronologically one after another or simultaneously (e.g. Hall, 1995; Westhead and Wright, 1998). Empirical evidence shows that earlier acquisition experience is positively related to future acquisition likelihood (Collins et al., 2009; Haleblian et al., 2006; Peng and Fang, 2010). According to Wright et al. (1997), habitual entrepreneurs' motivations differ from those of other types of entrepreneurs. Habitual entrepreneurs may have a vision, based on earlier business transfers, of how the acquired firm needs to be developed after the transfer. Habitual entrepreneurs may also foresee that a well-developed MCS may be valuable in the possible forthcoming business transfers from the perspective of a potential new acquirer. Further, habitual entrepreneurs might be more skilled in implementing governance devices such as MCS (Barney et al. 2001). Altogether, earlier experience in business transfer seems to have effect on the relationship between PBTMCSD and PBTS. H2 summarizes the earlier discussion in this subchapter:

H2a: The relationship between PBTMCSD and PBTS is moderated by the size of the acquired firm

H2b: The relationship between PBTMCSD and PBTS is moderated by the experience in business transfers of the acquirer. 


\section{Data and methods}

\section{Collection of empirical data}

The data for the study were collected in Finland in January 2012 as a web-based survey. A survey was pilot tested by three entrepreneurs in order to test unambiguous of items. A short phone interview preceded the actual survey. The purpose of the phone interview was to check that the survey is directed to the right firm (i.e. business transfer had really happened in the firm) and contact person (new owner-manager of acquired firm) and, moreover, to gather some background information (e.g. size of acquirer and acquired firm, industry, a type of business transfer, timing of business transfer) at the same time. The target group consisted of acquirers (both external buyers and family business successors) that had implemented business transfer during 20062011, and thus at minimum one and a half years had to have passes after the business transfer in this cross-sectional survey. The sample was gathered manually by identifying business transfers from newspapers and local media, because there is not available any public register for business transfer in Finland.

The questionnaire was addressed to owner-managers of the firms, because the firms are very small; in many cases they are the only possible informants. This reduces the importance of potential issues (e.g. responder bias) due to one person in each firm completing the survey. A total of 178 questionnaires were sent out, and 67 responses were received, the response rate being $38 \%$ which is in congruence with earlier response rates in Finland (e.g Harzing, 2000; Hyvönen, 2007 see also Chapman and Kihn, 2009). $31 \%$ of the respondents were family business successors, while $69 \%$ were external acquirers, either firms or individual persons. The largest acquired firm had 70 employees and $12 \%$ of the acquired firms were one-person-enterprises. 66 
$\%$ had 2-10 and $22 \%$ had more than 10 employees. The industries of the acquired firms were: 36 $\%$ services, $30 \%$ retail, $24 \%$ manufacturing and $10 \%$ construction.

\section{Measurement constructs}

PBTMCSD

We used six items to measure PBTMCSD. The instrument was modified from the studies of Baines and Langfield-Smith (2003), Cadez and Guilding (2008) and Silvola (2008). Following the question "To what extent have the following techniques changed after business transfer?", six MCS techniques were listed including 1) Quality management, 2) Product profitability analysis, 3) Customer profitability analysis, 4) Activity-based costing, 5) Budgeting, 6) Balanced scorecard. We applied a Likert-type scale from 1 (no change at all after business transfer) to 5 (change to a great extent). Cronbach alpha is 0.881 indicating a high reliability for the measure. This means that if all six MCS techniques are changed extensively it represents that PBTMCSD are developed more extensively than if only one MCS technique is extensively (or not at all) changed. However, the change is not a synonym for a good outcome which is measured by a different measurement construct (i.e. PBTS) in our study.

Panel A in Table 1 presents the descriptive statistics for the items. Eight respondents did not change their PBTMCSD at all and six respondents changed PBTMCSD extensively (graded 4 or more on average). Table 1 reports the frequencies of those extremes by each separate MCS technique. Acronym Q refers to the original item in questionnaire (i.e. Q17.9 is item 17.9 in the questionnaire). In practice, it might be challenging for a respondent to evaluate the extensiveness of the change of a particular MCS technique. However, no objective measure for the extensiveness of change is available. Thus we decided, in order to reduce construct validity 
problems, to follow earlier studies in measuring it (i.e. Baines and Langfield-Smith, 2003; Silvola, 2008). Also, we considered the possibility that firms in which the business transfer took place earlier have had better possibilities to assess the requirements for PBTMCSD and to perform the changes. Correlation (Pearson) analysis did not show any correlation between time elapsed since business transfer and PBTMCSD; hence degree of PBTMCSD does not appear to depend on the temporal dimension. We used both aggregate and specific items for PBTMCSD but no correlation was found.

\section{INSERT TABLE 1 ABOUT HERE}

PBTS

PBTS was measured by the modified instrument of Baines and Langfield-Smith (2003), Chapman and Kihn (2009) and Tsamenyi et al. (2011). Five items were used: 1) Number of employees, 2) Sales volume, 3) Profit, 4) Solvency and 5) Development of new products/services. For each of the five dimensions, the respondents were asked to evaluate their PBTS relative to their competitors on a scale of 1 (unsatisfactory) to 5 (excellent), i.e. the respondents compared their PBTS with competitors' in all five items. Hence, for instance the number of employees might decrease (or might be smaller than main competitors') but this might be viewed as preferable when a firm is trying to improve its cost efficiency and productivity. Some items might be challenging for the respondent to answer, due to item interpretation challenges or data availability issues (such as lack of accurate competitor information). However, in line with earlier users of the measure, we believe that the respondents know their most important competitors and are able to compare their own PBTS against their 
competitors'. Cronbach alpha is 0.859 for the measure. Descriptive statistics for the items are presented in Panel B in Table 1.

\section{Habitual entrepreneurs}

We used three items to measure habitual entrepreneurship. We modified the instrument of Wiklund and Shephard (2008) to better suit for the purposes of the study. The respondents were asked "before the business transfer, did you have earlier experience in 1) selling or 2) buying a firm or 3) start-ups"? The scale was based on respondent's subjective assessment about the number of transfers or start-ups and their depth of involvement, which was rated from 1 (no experience at all) to 5 (experience to a great extent). Thus the respondents with no earlier experience, except the business transfer upon which our survey focused, would rate their experience as 1 and correspondingly very experienced respondents (e.g. several different business transfers) as 5. The Cronbach alpha for the measure is 0.837 (Table 1). Panel $\mathrm{C}$ shows that a great number of respondents had no earlier experience of selling or buying a firm or of start-ups.

\section{Size of the acquired firm}

Several alternative indicators can be used for measuring firm size such as the number of employees, turnover or total assets (e.g. Chapman and Kihn, 2009; Chenhall, 2003). In the present study size is measured by the number of employees. A core purpose of MCS is to ensure that the behavior of employees is consistent with the objectives of a firm (Malmi and Brown, 2008). This indicates MCS to be more appropriate when the number of employees increases, since a higher number of employees may increase the possibility that the behavior of at least someone employees becomes inconsistent with the objectives. Also, in using the number of employees to measure size, were are in line with contingency-based studies which have 
extensively used number of employees for measuring the size (Chenhall, 2003). Table 2 presents the absolute number of employees in a sample. Logarithmic transformation was undertaken before the analysis due to data non-normality.

\section{Descriptive statistics}

Table 2 presents the descriptive statistics (Panel A) and correlation matrix (Panel B) for the used variables. Averages were used in forming the variables. Therefore, the number of responses in a single item can be lower than the number of responses in a measurement construct. This occurs if a respondent has not responded in all items of the measurement construct.

\section{INSERT TABLE 2 ABOUT HERE}

\section{Empirical results}

To test hypothesis 1 the following regression model was constructed.

$Y=\alpha_{0}+\beta_{1} X_{1}+\beta_{2} X_{2}+\beta_{3} X_{3}+e($ Model 1)

Where, $\mathrm{Y}$ is PBTS, $\mathrm{X}_{1}$ is PBTMCSD, $\mathrm{X}_{2}$ Habitual entrepreneurship, $\mathrm{X}_{3}$ is size of acquired (ln employees), $\alpha_{0}$ is constant, and $\mathrm{e}$ is the error term.

The results in Panel A, Table 3 show that $\beta_{1}$ is both positive and significant $\left(\beta_{1}=0.32, t=2,491\right.$, $\mathrm{p}=0.016$ ). The regression model explained $13 \%$ of the variance (adjusted $R^{2}$ ) in the dependent variable, PBTS $(\mathrm{F}=3,879, \mathrm{p}=0.014)$ after controlling the habitual entrepreneurship and acquired size. In addition to regression analysis, the correlation analysis shows the positive $(\mathrm{r}=$ 0.308) and significant $(\mathrm{p}=0.012)$ relationship between PBTMCSD and PBTS in Panel B Table 
2. Model 1 was tested also with several other control variables including acquisition type (such as business transfer among family members, see Sharma et al. 2001), business transfer year and external consultation resources used in the business transfer. However, the positive relationship between PBTMCSD and PBTS remained also with other control variables. Together, these results confirm our hypothesis (H1) that PBTMCSD has a positive relationship with PBTS.

To test hypothesis 2 we used the following regression Model 2.

$\mathrm{Y}=\alpha_{0}+\beta_{1} \mathrm{X}_{1}+\mathrm{e}($ Model 2)

Where, $\mathrm{Y}$ is PBTS, $\mathrm{X}_{1}$ is PBTMCSD, $\alpha_{0}$ is constant, and e is the error term.

Regression Model 2 was statistically tested separately for inexperienced and experienced acquirers when testing the effect of acquirer experience on the relationship between PBTMCSD and PBTS, i.e. H2b. The group of inexperienced rated their experience as values 1 (no earlier experience) and experienced had values over 1. According to panel B in Table 3, the relationship between PBTMCSD and PBTS was not found in the group of inexperienced $\left(\beta_{1}=0.014\right)$ whereas there was a positive and statistically significant relationship in experienced group $\left(\beta_{1}=0.469\right)$. Therefore, this result provides empirical support for Hypothesis $\mathrm{H} 2 \mathrm{~b}$; the relationship between PBTMCSD and PBTS is affected by the experience of the acquirer.

\section{INSERT TABLE 3 ABOUT HERE}

To test the effect of size of the acquired firm (Hypothesis H2a), the data were divided according to median. The respondent firms with median or fewer employees (4 employees) were labeled "micro firms" and the rest were labeled "small firms". Panel B in Table 3 shows that PBTMCSD 
and PBTS did not have statistical significant relationship $\left(\beta_{1}=0.115\right)$ for micro firms whereas a positive and statistical significant relationship was found for small firms $\left(\beta_{1}=0.528\right)$. Therefore, the results confirm that the relationship between PBTMCSD and PBTS is moderated by size of acquired firm as stated in Hypothesis 2a.

\section{Discussion and conclusions}

A business transfer is a strategic option for small firms when they are trying to develop and to grow their business. However, PBTS varies when some transfers are more successful than others. We focused on PBTS because the success of business transfer can be determined only after the business transfer. Different development activities can be implemented after a business transfer in the acquired firm. One important dimension is PBTMCSD, which has not been previously studied in the context of small business transfers. According to our empirical results PBTMCSD has a positive relationship with PBTS. The results contribute to earlier studies in several ways. First, the results indicate that PBTMCSD is important in the business transfer context. This may be due to benefits achieved during MCS development, such as improvement of organizational processes or increased understanding of the strengths and weaknesses of the firm. It might be that PBTMCSD leads to better information for decision making, thus improving PBTS. PBTMCSD may also support PBTS by promoting organizational adjustment.

Second, the results contribute to earlier studies based on contingency theory. Contrary to the contingency theory, we found PBTMCSD to be important for the PBTS also in small firms with five to seventy employees in the context of business transfers. One reason for this may be that in this particular context overall uncertainty is high, as there is e.g. an information asymmetry 
between the acquired and the acquiring firm, and therefore a broad scope of information is required even in small firms. According to the contingency theory (Chenhall, 2003), high uncertainty increases the information requirements in decision making. Our results suggest that all the contingency variables do not have a similar effect on information requirements. Some contingency variables (such as uncertainty) can be more important than others (such as size) in the business transfer context. Overall, our results show that PBTMCSD has a high relevance for PBTS in small firms.

Third, according to the empirical results, acquirer experience had an effect on the relationship between PBTMCSD and PBTS. We found that the relationship was stronger for the more experienced acquirers. However, in our empirical setting even the more experienced had only very limited earlier experience of business transfers. It appears that having any previous business transfer experience is important for the examined relationship; entrepreneurs with at least some previous business transfer experience are more likely to PBTMCSD with good PBTS in new business transfers. This might be because earlier business transfer experience improves the entrepreneur's capability to identify potential areas for PBTMCSD and to implement PBTMCSD in a way that contributes to PBTS. The result highlights again the advantage that habitual entrepreneurs have; possessing more entrepreneurial and managerial experience, they have more competence, tools and systems to develop their new businesses (e.g. Huovinen, 2007; Wright et al., 1997). Elsewhere it has been found that habitual entrepreneurs also utilize more external advisors in business transfer processes than non-habitual entrepreneurs (Varamäki et al., 2012). However, our statistical analyses did not find a direct relationship between business transfer experience and PBTS. This is in line with earlier business transfer studies: each process is a new challenge to management (Haspeslagh and Jemison, 1991) because every business transfer is a 
unique dynamic process (Teerikangas and Very, 2006). Due to the uniqueness of business transfer cases, the relationship between business transfer experience and PBTS is not straightforward.

Fourth, the results are highly suggestive from the perspective of small business management and provide some practical cues for small business owners considering a business transfer. First, the nature of resources should be considered in planning the transfer. According to RBV, acquisitions can be either supplementary or complementary with regards to resources (Wernerfelt, 1984). When the acquired resources are supplementary, there is less need for PBTMCSD, whereas with the acquisition of complementary resources there is more probably a need for PBTMCSD so as to meet the needs of PBTS. Hence, a small firm looking to buy another small firm in order to acquire complementary resources should plan on spending time and effort in PBTMCSD. Second, from the potential seller's perspective, investments into PBTMCSD might well pay off as higher valuations in business transfer negotiations: well-developed systems can provide better and more credible information and hence support the decision making process of the potential acquirer in the business transfer. Even the entrepreneurs with little appreciation for use of MCS should consider their value in the business transfer context specifically. All in all, our model can also be used to predict PBTS in SMEs if PBTMCSD is considered. The model underlines for potential buyers the importance of PBTMCSD and, hence, the potential for PBTS.

According to earlier studies, the business transfer process is a complex, multifaceted, and multitemporal phenomenon (Meglio and Risberg, 2010) and the integration process is an important success factor (Haspeslagh and Jemison, 1991) after the transfer. Our results show that in SME context MCS are a solid corner stone upon which to build and develop a business after business 
transfer. To RBV scholars these findings highlight two elements to be included among important resources: MCS and business transfer know-how. Both resources are advantageous for achieving success after executing a business transfer.

This study has some limitations. First, despite the satisfactory response rate, the sample size is quite small. The sample included all identified business transfers in the region; as there is no available public database on business transfers in Finland, and all transfers have to be manually collected from media, the coverage is not complete. Later studies should try for more extensive samples allowing for more fine-grained analysis. Second, due to the fairly limited data, we were only able to analyze the impact of firm size and habitual entrepreneurship on the relationship between PBTMCSD and PBTS. In later studies for example the impact of e.g. industry, type of business transfer (family succession vs. external buyer) and time elapsed since business transfer should be examined. Thirdly, the focus of this study was on PBTMCSD and hence issues connected with their actual use were not addressed (e.g. Länsiluoto et al., 2013). Finally, by exploiting qualitative research strategies, a better understanding of the role of MCS in different phases of business transfers should be sought, exploring e.g. the potential of pre-transfer MCS development for enhancing the value of the business and for increasing trust in negotiations. This research design should take into account both sellers' and buyers' perspectives.

\section{References}

Agarwal, R. and Helfat, C. (2009). Strategic renewal of organizations. Organization Science 20(2):281-293. 
Angwin, D. (2007). Motive archetypes in mergers and acquisitions (M\&A): the implications of a configurational approach to performance. in Finkelstein, S. and Cooper, C. (eds.), Advances in Mergers and Acquisitions 6:77-105.

Arikan, A. and McGahan, A. (2010). The development of capabilities in new firms. Strategic Management Journal 31 (1): 1-18.

Arvanitis, S. and Stucki, T. (2014). Do mergers and acquisitions among small and medium-sized enterprises affect the performance of acquiring firms?. International Small Business Journal. Epub ahead of print 27 February 2014. DOI: 10.1177/0266242614522280.

Ates, A. Garengo, P., Cocca, P. and Bititci, U. (2013). The development of SME managerial practice for effective performance management. Journal of Small Business and Enterprise Development 20(1):28-54.

Baines, A. and Langfield-Smith, K. (2003). Antecedents to management accounting change: a structural equation approach. Accounting, Organizations and Society 28(7-8):675-698.

Baker, H., Dutta, S., Saadi, S., and Zhu, P. (2012). Are good performers bad acquirers?. Financial Management 41(1):95-118.

Barkema, H. and Schijven, M. (2008). Toward unlocking the full potential of acquisitions: The role of organizational restructuring. Academy of Management Journal 51(4):696-722.

Barney, J. (2001). Resource-based theories of competitive advantage: A ten-year retrospective on the resource-based view. Journal of Management 27(6):643-650.

Barney, J., Wright, M. and Ketchen, D. (2001). The resource-based view of the firm: Ten years after 1991. Journal of Management 27(6):625-641.

Battisti, M. and Okamuro, H. (2010), Selling, Passing on or Closing? Determinants of Entrepreneurial Intentions on Exit Modes, Global CEO Hi-Stat Discussion Paper Series 151. Tokyo: Hitotsubashi University. 
Cadez, S. and Guilding, C. (2008). An exploratory investigation of an integrated contingency model of strategic management accounting. Accounting, Organizations and Society 33(78):836-863.

Chapman, C.S. and Kihn, L.-A. (2009). Information system integration, enabling control and performance. Accounting, Organizations and Society 34(2):151-169.

Chatterjee, S. (2009). The keys to successful acquisition programmes. Long Range Planning 42: $137-163$.

Chenhall, R. (2003). Management control systems design within its organizational context: findings from contingency-based research and directions for the future. Accounting Organizations and Society 28:127-168.

Chenhall, R.H. and Euske, K.J. (2007). The role of management control systems in planned organizational change: An analysis of two organizations. Accounting, Organizations and Society 32:601-637.

Collins, J.D., Holcomb, T.R., Certo, S.T., Hitt, M.A. and Lester, R. (2009). Learning by doing: Cross-border mergers and acquisitions. Journal of Business Research 62(12):1329-1334.

CSES (2013), Evaluation of the Implementation of the 2006 Commission Communication of Business Transfers. Final Report, available at: http://www.google.fi/url?sa=t\&rct=j\&q=\&esrc=s\&frm=1\&source=web\&cd=2\&ved=0CC4 QFjAB\&url=http\%3A\%2F\%2Fec.europa.eu\%2FDocsRoom\%2Fdocuments\%2F4263\%2Fa ttachments\%2F4\%2Ftranslations\%2Fns\%2Frenditions\%2Fpdf\&ei=BbsNVMXRNOLNyg O8yoGACQ\&usg=AFQjCNFzGRDZPtI3RGLa4dQ1B0Ce4zXjMA (accessed 8 September 2014).

Delmar, F., Davidsson, P. and Gartner, W. (2003). Arriving at the high-growth firm. Journal of Business Venturing 18(2):401-405. 
Dyck, B., Mauws, F. Starke, A. and Mischke, G. (2002). Passing the baton: the importance of sequence, timing, technique and communication in executive successions. Journal of Business Venturing 17(2):143-162.

Edinburgh group (2015) Growing the global economy through SMEs. Available at: http://www.edinburgh-group.org/media/2776/edinburgh_group_research__growing_the_global_economy_through_smes.pdf (accessed 28 May 2015).

European Commission (2002), Final Report of the Expert Group on the Transfer of Small and Medium-sized Enterprises, European Commission, Brussels. Available at: http://ec.europa.eu/enterprise/policies/sme/files/support_measures/transfer_business/transfe r_com_02/final_report_en.pdf (accessed 24 September 2014)

European Commission (2011), Business Dynamics: Start-ups, Business Transfers and Bankruptcy, available at: http://ec.europa.eu/enterprise/policies/sme/businessenvironment/files/business_dynamics_final_report_en.pdf (accessed 1 December 2011).

Franco-Santos, M., Lucianetti, L. and Bourne, M. (2012). Contemporary performance measurement systems: A review of their consequences and a framework for research. Management Accounting Research 23(2):79-119.

Garengo, P., Biazzo, S. and Bititci U.S. (2005) Performance measurement systems in SMEs: A review for a research agenda. International Journal of Management Reviews 7(1): 25-47.

Granlund, M. (2003). Management accounting system integration in corporate mergers: A case study. Accounting, Auditing \& Accountability Journal 16(2):208-243.

Grant, R.M. (1991). The resource-based theory of competitive advantage: implications for strategy formulation. California Management Review 33(3):114-122.

Guest, P.M., Bild, M. and Runsten, M. (2010). The effect of takeovers on the fundamental value of acquirers. Accounting and Business Research 40(4):333-352. 
Halabí, C.E. and Lussier, R.N. (2014),"A model for predicting small firm performance", Journal of Small Business and Enterprise Development 21(1):4-25.

Haleblian, J., Kim, J.-Y. and Rajagopalan, N. (2006). The influence of acquisition experience and performance on acquisition behavior: Evidence from the U.S. commercial banking industry. Academy of Management Journal 49(2):357-370.

Hall, P. (1995). Habitual owners of small businesses. in Chittenden, F., Robertson, M. and Marshall, I. (eds.) Small Firms: Partnership for Growth, Paul Chapman publishing, London):217-230.

Harzing, A.-W. (2000) Cross-national industrial mail surveys: Why do response rates differ between countries?. Industrial Marketing Management 29(3):243-254.

Haspeslagh, P. and Jemison, D. (1991), Managing Acquisitions: Creating Value through Corporate Renewal, Free Press, New York.

Hoque, Z. and Chia, M. (2012). Competitive forces and the levers of control framework in a manufacturing setting: A tale of a multinational subsidiary. Qualitative Research in Accounting \& Management 9(2):123-145.

Howorth, C., Westhead, P. and Wright, M. (2004). Buyouts, information asymmetry and the family management dyad. Journal of Business Venturing 19(4):509-534.

Huovinen, J. (2007), Tapayrittäjyys - Tilannetekijät Toiminnan Taustalla ja Yrittäjäkokemuksen Merkitys Yritystoiminnassa, $\mathrm{PhD}$ Thesis, Kuopion yliopiston julkaisuja H, Informaatioteknologia ja kauppatieteet 7.

Hutchinson, V. and Quintas, P. (2008). Do SMEs do Knowledge Management?: Or Simply Manage what they Know? International Small Business Journal 26(2):131-154. 
Hyvönen, J. (2007). Strategy, performance measurement techniques and information technology of the firm and their links to organizational performance. Management Accounting Research 18(3):343-366.

Kohn, K. and Spengler, H. (2009), KfW-Gründungsmonitor 2009. Ab wärtsdynamik im Gründungsgeschehen gebremst - weiterhin wenige innovative Projekte, $\mathrm{KfW}$ Bankengruppe, Frankfurt am Main. Available at: https://www.kfw.de/DownloadCenter/Konzernthemen/Research/PDF-DokumenteGr\%C3\%BCndungsmonitor/Gr\%C3\%BCndungsmonitor-2009-lang.pdf $\quad$ (accessed 8 September 2014).

Kreitl, G. and Oberndorfer, W.J. (2004). Motives for acquisitions among engineering consulting firms. Construction Management \& Economics 22(7):691-700.

Laitinen, E.K., Länsiluoto, A. and Rautiainen, I. (2009). Extracting appropriate scope for information systems: a case study. Industrial Management \& Data Systems 109(3):305321.

Lansberg, I. (1988). The succession conspiracy. Family Business Review 1(2):119-143.

Le Breton-Miller, I., Miller, D. and Steier, L. (2004). Toward an integrative model of effective FOB succession. Entrepreneurship Theory and Practice 28(4):305-328.

Luft, J. and Shields, M. (2003). Mapping management accounting: graphics and guidelines for theory-consistent empirical research. Accounting, Organizations and Society 28(2-3):169249.

Länsiluoto, A., Järvenpää, M. and Krumwiede, K. (2013). Conflicting interests but filtered key targets: Stakeholder and resource-dependency analyses at a University of Applied Sciences. Management Accounting Research 24(3):228-245. 
Malmi, T. and Brown, D. (2008). Management control systems as a package-Opportunities, challenges and research directions. Management Accounting Research 19(4):287-300.

Marks, M. and Mirvis, P. (1992). Rebuilding after the merger: Dealing with 'survivor sickness'. Organizational Dynamics 21(2):18-32.

Marks, M. and Mirvis, P. (2001). Making mergers and acquisitions work: Strategic and psychological preparation. Academy of Management Executive 15:80-92.

Meglio, O. and Risberg, A. (2010). Mergers and acquisitions - Time for a methodological rejuvenation of the field. Scandinavian Journal of Management 26(1):87-95.

Meglio, O. and Risberg, A. (2011). The (mis)measurement of M\&A performance-A systematic narrative literature review. Scandinavian Journal of Management 27(4):418-433.

Moilanen, S. (2008). The role of accounting and an intermediate subsidiary in the management control system. Management Accounting Research 19(3):252-269.

Morris, M., Williams, R., Allen, J. and Avila, R. (1997). Correlates of success in family business transitions. Journal of Business Venturing 12(5):385-401.

Nixon, B. and Burns, J. (2012). The paradox of strategic management accounting. Management Accounting Research 23(4):229-244.

Peng, Y.-S. and Fang, C.-P. (2010). Acquisition experience, board characteristics, and acquisition behavior. Journal of Business Research 63(5):502-509.

Priem, R. and Butler, J. (2001). Is the resource-based theory a useful perspective for strategic management research?. Academy of Management Review 26(1):22-40.

Reheul, A.-M. and Jorissen A. (2014),"Do management control systems in SMEs reflect CEO demographics?", Journal of Small Business and Enterprise Development 21(3):470 - 488.

Risberg, A. (2001). Employee experience of acquisition processes. Journal of World Business 31(1):58-84. 
Seth, A., Song, K. and Pettit, R. (2002). Value creation and destruction in cross-border acquisitions: An empirical analysis of foreign acquisitions of US firms. Strategic Management Journal 23: 921-940.

Sharma, P., Chrisman, J. and Chua, J. (2003). Predictors of satisfaction with the succession process in family firms. Journal of Business Venturing 18(5):667-687.

Sharma, P., Chrisman, J., Pablo, A. and Chua, J. (2001). Determinants of initial satisfaction with the succession process in family firms: A conceptual model. Entrepreneurship: Theory \& Practice 25(3):17-35.

Shi, W., Sun, J. and Prescott, J. (2012). A temporal perspective of merger and acquisition and strategic alliance initiatives: review and future directions. Journal of Management 38(1):164-209.

Silvola, H. (2008). Do organizational life-cycle and venture capital investors affect the management control systems used by the firm?. Advances in Accounting 24(1):128-138.

Stahl, G., Larsson, R., Kremershof, I. and Sitkin, S. (2011). Trust dynamics in acquisitions: A case survey. Human Resource Management 50 (5): 575-603.

Taticchi, P., Tonelli, F. and Cagnazzo, L. (2010). Performance measurement and management: a literature review and a research agenda. Measuring Business Excellence 14(1): 4-18.

Teittinen, H., Pellinen, J. and Järvenpää, M. (2013) ERP in action — Challenges and benefits for management control in SME context. International Journal of Accounting Information Systems 14(4):278-296.

Teerikangas, S. and Very, P. (2006). The culture - performance relationship in M\&A: From yes/no to how. British Journal of Management 17(1):31-48. 
Tillema, S. (2005). Towards an integrated contingency framework for MAS sophistication: Case studies on the scope of accounting instruments in Dutch power and gas companies. Management Accounting Research 16(1):101-129.

Tsamenyi, M., Sahadev, S. and Shi Qiao, Z. (2011). The relationship between business strategy, management control systems and performance: Evidence from China. Advances in Accounting 27(1):193-203.

Uhlaner, R. and West, A. (2008). Running a winning M\&A shop. McKinsey Quarterly 2008(2):106-113.

Van Teeffelen, L. (2012), Avenues to improve success in SME business transfers: reflections on theories, research and policies, Hogeschool Utrecht, Utrecht.

Varamäki, E., Tall, J., Sorama, K., Länsiluoto, A., Viljamaa, A., Laitinen, E.K., Järvenpää, M. and Petäjä, E. (2012), Liiketoiminnan kehittyminen omistajanvaihdoksen jälkeen Casetutkimus omistajanvaihdoksen muutostekijöistä, Seinäjoen ammattikorkeakoulun julkaisusarja A9, Seinäjoki University of Applied Sciences, Seinäjoki.

Varamäki, E., Tall, J. and Viljamaa, A. (2014), Business transfer and successions in Finland from the potential sellers' and predecessor's perspective, in: Gnan, L., Lundberg, H., Songini, L. and Pellegrini, M. (eds.), Advancing European Entrepreneurship Research: Entrepreneurship as a working attitude, a mode of thinking and an everyday practice, A volume in: The Entrepreneurship SIG at European Academy of Management: New Horizons with strong Traditions, Information Age Publishing):55-80.

Westhead, P. and Wright, M. (1998). Novice, portfolio, and serial founders: are they different?. Journal of Business Venturing 13(3):173-205.

Wernerfelt, B. (1984). A resource-based view of the firm. Strategic Management Journal 5(2):171-180. 
Wiklund, J. and Shepherd, D. (2008). Portfolio entrepreneurship: Habitual and novice,founders, new entry and mode of organizing. Entrepreneurship Theory and Practice 32(4): 701-725.

Wright, M., Robbie, K. and Ennew, C. (1997). Venture capitalists and serial entrepreneurs. Journal of Business Venturing 12(3):227-249.

Wymenga, P., Spanikova, V., Barker, A., Konings, J. and Canton, E. (2012), EU SMEs in 2012: At the Crossroads. Annual Report on Small and Medium-sized Enterprises in the EU, 2011/12, Report for the European Commission.

Zollo, M. and Meier, D. (2008). What Is M\&A performance?. Academy of Management Perspectives 22(3):55-77.

\section{Acknowledgements}

This research project has been funded by European Social Foundation and the support is gratefully acknowledged. We appreciate also the contribution of respondents for their time to complete questionnaire. Finally, we would like to thank anonymous reviewers and editor-in-chief Wee-Liang Tan for their constructive comments. 


\section{Tables and Figures.}

Table 1. Descriptive statistics for the measures and items.

Panel A. PBTMCSD (Cronbach alpha .881)

\begin{tabular}{|c|c|c|c|c|c|c|}
\hline & $\mathrm{N}$ & Mean & Median & $\begin{array}{l}\text { No chan- } \\
\text { ge }(\mathrm{N})\end{array}$ & $\begin{array}{l}\text { Great } \\
\text { change (N) }\end{array}$ & $\begin{array}{l}\text { Std. } \\
\text { Dev. }\end{array}$ \\
\hline Quality management (Q17.9) & 66 & 2,86 & 3 & 13 & 8 & 1,311 \\
\hline Product profitability analysis (Q17.10) & 66 & 2,61 & 3 & 19 & 5 & 1,323 \\
\hline Customer profitability analysis (Q17.11) & 62 & 2,40 & 2 & 22 & 3 & 1,311 \\
\hline Activity-based costing (Q17.12) & 65 & 2,51 & 2 & 19 & 5 & 1,288 \\
\hline Budgeting (Q17.13) & 65 & 2,74 & 3 & 15 & 9 & 1,350 \\
\hline Balanced scorecard (Q17.14) & 61 & 1,80 & 1 & 34 & 1 & 1,046 \\
\hline
\end{tabular}

Panel B. PBTS (Cronbach alpha .859)

\begin{tabular}{lllllll} 
& N & Mean & Median & $\begin{array}{l}\text { Unsatis- } \\
\text { factory }\end{array}$ & Excellent & $\begin{array}{c}\text { Std. } \\
\text { Dev. }\end{array}$ \\
\hline Employee numbers (Q18.1) & 65 & 3,03 & 3 & 4 & 4 & 0,951 \\
Sales volume (Q18.2) & 64 & 3,23 & 3 & 0 & 5 & 0,921 \\
Profit (Q18.03) & 64 & 2,98 & 3 & 4 & 4 & 1,000 \\
Solvency (Q18.04) & 62 & 3,06 & 3 & 3 & 7 & 1,006 \\
Development of new products/services (Q18.05) & 65 & 3,26 & 3 & 1 & 6 & 0,940
\end{tabular}

Panel C. Habitual entrepreneurship (Cronbach alpha .837)

\begin{tabular}{|c|c|c|c|c|c|c|}
\hline & $\mathrm{N}$ & Mean & Median & $\begin{array}{l}\text { No expe- } \\
\text { rience } \\
(\mathrm{N})\end{array}$ & $\begin{array}{l}\text { Great expe- } \\
\text { rience }(\mathrm{N})\end{array}$ & $\begin{array}{l}\text { Std. } \\
\text { Dev. }\end{array}$ \\
\hline Experience in selling a firm (Q4.3) & 65 & 1,86 & 1 & 43 & 5 & 1,379 \\
\hline Experience in buying a firm (Q4.4) & 63 & 2,05 & 1 & 38 & 5 & 1,442 \\
\hline Experience in establishing a firm (Q4.5) & 64 & 2,58 & 2 & 28 & 14 & 1,650 \\
\hline
\end{tabular}


Table 2. Descriptive statistics for the variables.

Panel A. Descriptive statistics for the variables

$\begin{array}{lllll} & \text { PBTMCSD } & \text { PBTS } & \begin{array}{l}\text { Habitual } \\ \text { Entre }\end{array} & \begin{array}{l}\text { Size } \begin{array}{c}\text { (number of } \\ \text { employees) }\end{array} \\ \hline \mathrm{N}\end{array} \\ \text { Number of items } & 66 & 65 & 65 & 65 \\ \text { Mean } & 6 & 5 & 3 & 1 \\ \text { Median } & 2,474 & 3,127 & 2,169 & 8,762 \\ \text { Mode } & 2,583 & 3,250 & 1,667 & 4,000 \\ \text { Std. Deviation } & 1,000 & 3,250 & 1,000 & 2,000 \\ \text { Minimum } & 1,028 & 0,798 & 1,298 & 11,812 \\ \text { Maximum } & 1,000 & 1,250 & 1,000 & 1 \\ & 4,333 & 5,000 & 5,000 & 70\end{array}$

Panel B. Correlations between variables (Pearson)

\begin{tabular}{lllll} 
& PBTMCSD & PBTS & Habit. Entre. & Size (employees) \\
\hline PBTMCSD & 1 & & & \\
PBTS & $0,308^{*}$ & 1 & & \\
Habitual Entre. & $0,330^{* *}$ & $0,249^{*}$ & 1 & 1 \\
Size (Ln employees) & 0,159 & 0,141 & 0,241 & 1 \\
*significant at the 0.05 level (2-tailed); & ** significant at the 0.01 level (2-tailed)
\end{tabular}


Table 3. Empirical test of the relationships

Panel A. Relationship between PBTMCSD and PBTS

\begin{tabular}{lccccc} 
Variable & & Coefficient & Std. Error & t-value & $\mathrm{p}$-value \\
\hline Constant & & 2,182 & 0,287 & 7,606 & 0,000 \\
PBTMCSD & $\beta_{1}$ & 0,320 & 0,102 & 2,491 & 0,016 \\
Control variables: & & & & & \\
Habitual Entre. & $\beta_{2}$ & 0,155 & 0,085 & 1,191 & 0,238 \\
Size (ln employees) & $\beta_{3}$ & 0,042 & 0,094 & 0,337 & 0,737 \\
$\mathrm{R}^{2}$ (adjusted R ${ }^{2}$ ) & \multicolumn{2}{c}{$0,17(0,13)$} \\
F-test = 3,879, p-value $=0.014, \mathrm{~N}=60$ & & &
\end{tabular}

Panel B. Relationship between PBTMCSD and PBTS in subgroups (moderation)

\begin{tabular}{ll|ll|ll|} 
& & \multicolumn{2}{|l|}{ Habitual entrepreneurship } & Size of acquired \\
& All data & Inexperienced & Experienced & Micro & Small \\
Variable & Coefficient & Coefficient & Coefficient & Coefficient & Coefficient \\
\hline Constant & $2,504^{* * *}$ & $2,970^{* * *}$ & $2,224^{* * *}$ & $2,814^{* * *}$ & $2,073^{* * *}$ \\
PBTMCSD & $0,308^{* *}$ & 0,014 & $0,469^{* * *}$ & 0,115 & $0,528^{* * *}$ \\
R2 (adjusted R2) & $0,10(0,08)$ & $0,000(-0,041)$ & $0,220(0,198)$ & $0,013(-0,017)$ & $0,528(0,253)$ \\
F-test & 6,616 & 0,005 & 9,890 & 0,44 & 10,822 \\
p-value & 0,012 & 0,946 & 0,003 & 0,51 & 0,003 \\
N & 64 & 25 & 36 & 32 & 29 \\
*significant at the 0.1 level; ${ }^{* *}$ significant at the 0.05 level; ${ }^{* * *}$ significant at the 0.01 level
\end{tabular}

Figure 1. Theoretical model

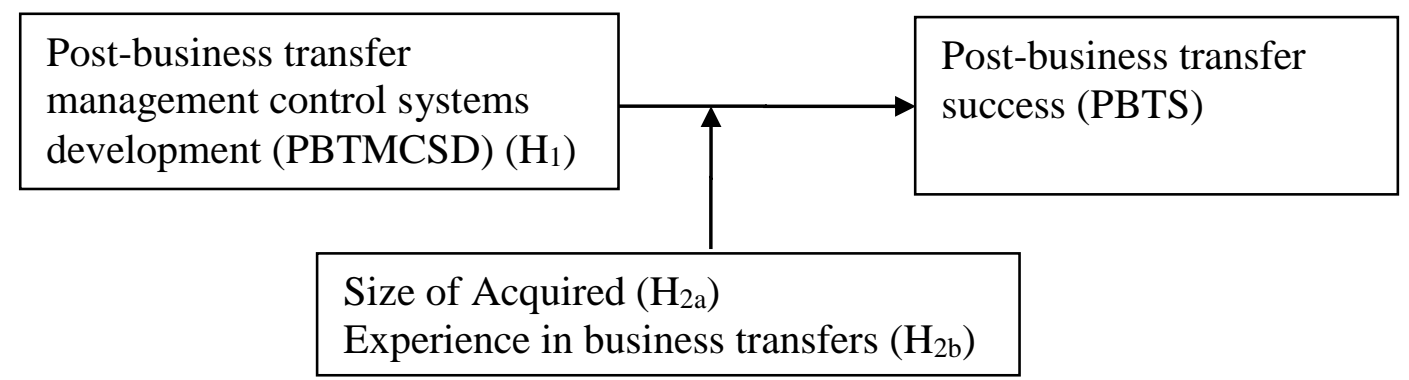

